\title{
Association Between Social Media and Psychological Effects Among Adolescents: A School Based Cross-Sectional Study in Kathmandu City of Nepal
}

\section{Ashok Paudel ( $\square$ ashokkpaudel@gmail.com )}

Department of Public Health, National Open College, Pokhara University, Lalitpur, Nepal

Muni Chhetri

Karnali Academy of Health Sciences, Jumla, Nepal

Prinisha Baidya

Department of Public Health, National Open College, Pokhara University, Lalitpur, Nepal

\section{Research Article}

Keywords: Adolescents, Cell phone, Depression, Social media, Social media addiction

Posted Date: January 27th, 2021

DOl: https://doi.org/10.21203/rs.3.rs-140958/v1

License: (c) (1) This work is licensed under a Creative Commons Attribution 4.0 International License.

Read Full License 


\section{Abstract}

Background: Social media are comprised of websites and software applications that enable users to create and share content or to participate in social networking. Inappropriate use of social media may lead to negative psychological effects. This study aimed to assess the psychological effects of social media among adolescent students of Grade 9 and 10 in Kathmandu city of Nepal.

Methods: A Cross-sectional school-based study done among randomly sampled adolescent students (10$19 \mathrm{yrs}$ ) of Grade 9 and 10 . Total 318 sample size derived using the formula: $n=z^{2} p q / e^{2}$. Social Media Addiction Scale Student Form and Short Mood and Feelings Questionnaire were the self-administered data collection tools. The purpose of the study was explained to respondents. Ethical approval was obtained through the Ethical Review Board of Nepal Health Research Council. Data were analyzed on Scientific Package for Social Science version-20.

Results: About sixty-two percent of the adolescents had their cell phones and 88.1 percent had internet facilities in their houses. Forty-six percent of adolescents were addicted to social media and 68.2 percent were depressed. Out of depressed adolescents, 64.4 percent of them had social media addiction. The significant association observed between adolescents with their cell phone and social media addiction $(p=0.037)$; social media addiction and depression $(p=0.000)$.

Conclusions: Adolescents with their cell phone is associated with social media addiction and social media addiction is associated with depression, suggesting an urgent need to develop policies and programs to mitigate negative psychological effects of cell phones and social media addiction.

\section{Background}

Social media are web-based communication tools and applications that allow people to interact, and share by both sharing and receiving information quickly and efficiently $[1,2]$. The use of social media is currently one of the most popular leisure activities among adolescents [3-5] and it hosts virtual communities where users can create individual public and private profiles [6-8]. Users can access social media on different platforms (cell phone or computer devices), and for different activities (e.g., interacting with real-life friends, chatting, emailing, sharing, or creating pictures, videos, dating, playing games etc [9, 10]. Nowadays, the use of technology and the internet has been increasing and this increase brings along social, psychological, and physical problems. Social media addiction is one of the problems that arise from intensive internet and technology use and it has both positive and negative effects on human life [11].

Adolescents are individuals between 10-19 years of age [12], who easily swayed by emotions and perceive relatively small things as a big issue due to which their psychology is affected. Adolescent take interest in new things and get easily habituated to it leading to addiction. The access and use of social media are increasing rapidly among adolescents in Nepal. Contents of social media may lead to negative psychological effects in adolescents like addiction, depression, anxiety, stress etc. Previous studies 
showed increased use of social media among adolescents [3-5] and the increased number of adolescent social media users could explain the higher prevalence of psychological effects in this group [6, 8]. So, we conducted this cross-sectional school-based study to assess the psychological effects of social media among adolescent students (10-19 yrs) of Grade 9 and 10 in schools of Kathmandu city in Nepal.

\section{Methods}

We conducted this cross-sectional school-based survey among adolescents (10-19 yrs) of Grade 9 and 10 in schools of Kathmandu city from 6 th to 16 th January 2020. The study population was selected through a multistage sampling technique. Five schools of Kathmandu city were identified by the simple random sampling method. Adolescent students (10-19 yrs) studying in Grade 9 and 10 of those schools were the study population.

For the selection of adolescents from each of the schools, the attendance register of the students was used. We prepared a separate list of adolescent students studying in Grade 9 and 10 of those five schools. Adolescent student (10-19 yrs) studying in Grade 9 and 10, willing to participate and present on the study schedule were included in the study and others were excluded. We derived sample size by using the formula: $n=z^{2} p q / e^{2}$ (where, $n=$ required sample size, $z=1.96$, considering $95 \% C l, p=0.27, q=0.73$, $e$ $=$ level of precision (5\%). With the addition of five percent non-response rate, the total sample was 318 students (10-19 yrs) studying in Grade 9 and 10. Desired numbers of adolescents from each school were identified through Probability Proportional to Size (PPS) technique. Finally, a simple random sampling technique was used to select adolescents for data collection from five sampled schools.

Social Media Addiction Scale Student Form (SMAS-SF) [13], and Short Mood and Feelings Questionnaire (SMFQ) [14] were two sets of tools used for data collection. SMAS-SF is a 5-point Likert type scale used to assess the level of social media addiction. This scale is found valid and reliable enough to be used in determining the social media addictions among school and University students [13]. It consists of 29 items grouped in 4 dimensions (1-5 lies in virtual tolerance, 6-14 lies in virtual communication, 15-23 items lies in virtual problem sub-dimension and 24-29 items lie in virtual information). The scale includes 3 positive and 2 negative items. The five-point grading is used in this tool: 1) Definitely not appropriate (score = 1), 2) Not appropriate (score = 2), 3) Undecided (score = 3), 4) Appropriate (score =4) and 5) Quite appropriate (score $=5$ ). The highest point that can be scored using the scale is 145 , and the least that can be scored is 29. A higher score is more indicative of the person being a 'social media addict'. Next, SMFQ was also used as a screening tool to assess suspected depression among adolescents. The SMFQ are free and simple instruments used to identify depression and measure symptom change in adolescents [15] that shows reasonable psychometric properties for identifying children in early adolescence with a depressive disorder [14] and is potential for depression screening of detained adolescents [16]. There are 13 questions in total and are ranked as: Not true (score $=0$ ), Sometimes (score $=1)$ and True (score $=2)$. A total score of 8 or more is considered as 'depressed' and 7 or below score as 'not depressed'. 
Both SMAS-SF and SMFQ tools were self-administered by the same group of adolescents studying in Grade 9 and 10. SMAS-SF and SMFQ were pretested, edited, and finalized before data collection. The purpose of the study was explained to the respondents before data collection; written informed consent had been obtained from the respondents and ethical approval from Ethical Review Board of Nepal Health Research Council (NHRC)/Nepal had been received. Respondents were instructed to return the questionnaire after completion. For completeness, the collected data were edited, reviewed, and checked. To assure anonymity, code numbers were given on completed questionnaires after they were returned to the investigator. Statistical Package for Social Sciences (SPSS) version 20 was used to analyze the data. We used percent distribution and made comparisons for descriptive analysis and Chi-square test to assess associations between dependent and independent variables.

\section{Results}

A total of 318 adolescent respondents from Grade 9 and 10 completed the survey. Table 1 provides sample characteristics, accessibility of cell phone and internet facility, and time spent on social media.

Out of the total 318 respondents, 61.6 percent had their cell phones and a large proportion (88.1\%) of the respondents had internet facilities in their houses. Result also disclosed that the average time spent in social media was 2.44 hours in a day and a large proportion (54.4\%) of the respondents spent 1 to 5 hours in social media. 
Table 1

Access of cell phone, internet facility and time spent on social media $(\mathrm{N}=$ 318)

\begin{tabular}{|lll|}
\hline Variables & Frequency & Percent \\
\hline Age (completed yrs) & 39 & 12.3 \\
$12-13$ & 242 & 76.1 \\
$14-15$ & 37 & 11.6 \\
$>15$ & & \\
Gender & 167 & 52.5 \\
Boys & 150 & 47.2 \\
Girls & 1 & 0.3 \\
Bisexual & & \\
\hline School Grade & 140 & 44.0 \\
9th grade & 178 & 56.0 \\
10 th grade & & \\
\hline Respondents with their cell phone & 196 & 61.6 \\
Yes & 122 & 38.4 \\
No & & \\
\hline Access to internet facility at home & 280 & 0.3 \\
Yes & 38 & 11.9 \\
No & & \\
\hline Time spent on social media & 139.1 \\
$<1$ hour & 173 & \\
$1-5$ hours & 5 & \\
$6-10$ hours & 1 & \\
$>10$ hours & Maximum: & \\
Mean \pm SD: $2.44 \pm 1.8$ & & \\
\hline Source: Field survey, 2020 & & \\
\hline
\end{tabular}

Prevalence of social media addiction among adolescents had been assessed based on SMAS-SF. Table 2 shows the distribution of social media addiction among adolescents. Out of 318 respondents, 
45.9 percent of the adolescents were found addicted to social media. According to the findings of SMASSF, the total score of all adolescence students was 25,297 . The score of all four groups of the SMAS-SF was: virtual tolerance- 15.7 percent, virtual communications- 33 percent, virtual problem- 28.5 percent, and virtual information- 22.8 percent. 
Table 2

Social media addiction scale student form (SMAS-SF) related findings $(\mathrm{N}=318)$

\begin{tabular}{|c|c|c|c|c|c|}
\hline Responses & $\begin{array}{l}\text { Strongly } \\
\text { disagree }\end{array}$ & Disagree & Neutral & Agree & $\begin{array}{l}\text { Strongly } \\
\text { agree }\end{array}$ \\
\hline I am crazy to go on social media & 12.9 & 31.1 & 137.4 & 15.1 & 13.5 \\
\hline $\begin{array}{l}\text { I look for internet connectivity everywhere; to } \\
\text { go on social media }\end{array}$ & 16.0 & 31.1 & 17.9 & 29.2 & 5.7 \\
\hline $\begin{array}{l}\text { Going on social media is the first thing; I do } \\
\text { when I wake up in the morning }\end{array}$ & 39.3 & 36.8 & 10.7 & 10.1 & 3.1 \\
\hline $\begin{array}{l}\text { I see social media as an escape from the real } \\
\text { world }\end{array}$ & 23.2 & 30.8 & 24.4 & 15.7 & 6.0 \\
\hline $\begin{array}{l}\text { A life without social media becomes } \\
\text { meaningless for me }\end{array}$ & 19.5 & 27.4 & 34.9 & 13.8 & 4.4 \\
\hline $\begin{array}{l}\text { I prefer to use social media even though there } \\
\text { is somebody around me }\end{array}$ & 8.5 & 21.7 & 28.0 & 38.4 & 3.5 \\
\hline $\begin{array}{l}\text { I prefer the friendships on social media to the } \\
\text { friendships in real life }\end{array}$ & 37.1 & 28.8 & 16.4 & 14.2 & 3.5 \\
\hline $\begin{array}{l}\text { I express myself better to the people with } \\
\text { whom I get in contact with on social media }\end{array}$ & 23.6 & 36.5 & 18.6 & 17.0 & 4.4 \\
\hline I am as I show myself on social media & 4.7 & 7.9 & 15.7 & 48.4 & 23.3 \\
\hline $\begin{array}{l}\text { I usually prefer to communicate with people } \\
\text { via social media }\end{array}$ & 4.4 & 25.2 & 28.0 & 37.7 & 4.7 \\
\hline $\begin{array}{l}\text { Even though my family gets angry, I cannot } \\
\text { give up using social media }\end{array}$ & 26.7 & 35.8 & 20.1 & 13.2 & 4.1 \\
\hline $\begin{array}{l}\text { I want to spend time on social media when I } \\
\text { am alone }\end{array}$ & 4.7 & 5.3 & 15.4 & 56.3 & 18.2 \\
\hline $\begin{array}{l}\text { I prefer virtual communication on social } \\
\text { media to going out }\end{array}$ & 18.2 & 33.0 & 29.2 & 16.0 & 3.5 \\
\hline Social media activities affect my everyday life & 7.9 & 23.6 & 34.6 & 25.2 & 8.8 \\
\hline $\begin{array}{l}\text { I neglect my homework because I spend } \\
\text { much time on social media }\end{array}$ & 27.0 & 37.7 & 16.7 & 14.5 & 4.1 \\
\hline $\begin{array}{l}\text { I feel bad if I have to decrease the time, I } \\
\text { spend on social media }\end{array}$ & 19.5 & 35.2 & 24.8 & 16.3 & 3.8 \\
\hline I feel unhappy when I am not on social media & 15.4 & 37.4 & 29.6 & 12.6 & 5.0 \\
\hline Being on social media excites me & 6.9 & 8.5 & 32.7 & 42.8 & 9.1 \\
\hline
\end{tabular}




\begin{tabular}{|c|c|c|c|c|c|}
\hline Responses & $\begin{array}{l}\text { Strongly } \\
\text { disagree }\end{array}$ & Disagree & Neutral & Agree & $\begin{array}{l}\text { Strongly } \\
\text { agree }\end{array}$ \\
\hline $\begin{array}{l}\text { I use social media so frequently that I come in } \\
\text { conflict with my family/ disliked by my family }\end{array}$ & 43.7 & 30.8 & 13.8 & 10.7 & 0.9 \\
\hline $\begin{array}{l}\text { The mysterious world of social media always } \\
\text { pulls me towards itself }\end{array}$ & 10.7 & 24.8 & 31.8 & 28.9 & 3.8 \\
\hline $\begin{array}{l}\text { I do not even notice I am thirsty or hungry } \\
\text { when I am on social media }\end{array}$ & 34.9 & 35.5 & 12.6 & 10.4 & 6.6 \\
\hline $\begin{array}{l}\text { I notice that my productivity/capacity has } \\
\text { decreased due to social media }\end{array}$ & 11.6 & 26.1 & 27.7 & 26.4 & 8.2 \\
\hline $\begin{array}{l}\text { I have physical problems because of social } \\
\text { media use }\end{array}$ & 38.4 & 39.3 & 11.9 & 8.5 & 1.9 \\
\hline $\begin{array}{l}\text { I use social media even when walking on the } \\
\text { road to be instantly informed about } \\
\text { developments }\end{array}$ & 56.0 & 28.9 & 9.1 & 5.0 & 0.9 \\
\hline $\begin{array}{l}\text { I like using social media to keep myself } \\
\text { informed about what happens }\end{array}$ & 3.5 & 6.0 & 12.3 & 52.5 & 25.8 \\
\hline $\begin{array}{l}\text { I use social media to keep myself informed } \\
\text { about what social media groups share }\end{array}$ & 4.7 & 12.9 & 32.4 & 43.1 & 6.9 \\
\hline $\begin{array}{l}\text { I spend more time on social media to see } \\
\text { some special announcements (E.g. birthdays) }\end{array}$ & 9.7 & 24.2 & 28.0 & 133.3 & 4.7 \\
\hline $\begin{array}{l}\text { Keeping informed about the things related to } \\
\text { my courses (e.g. homework, activities) makes } \\
\text { me always stay on social media }\end{array}$ & 2.5 & 13.2 & 25.5 & 43.7 & 15.1 \\
\hline $\begin{array}{l}\text { I am always active on social media to be } \\
\text { instantly informed about what my friends and } \\
\text { relatives share }\end{array}$ & 17.0 & 27.7 & 31.1 & 19.2 & 5.0 \\
\hline Source: Field survey, 2020 & & & & & \\
\hline
\end{tabular}

Association between the dependent and independent variables has been measured by using the Chisquare test. Out of a total of 146 social media addict adolescents, more than two-thirds (67.8\%) owned a cell phone. As shown in Table 3, since the p-value is less than $0.05(p=0.037)$, significant association has been observed between adolescents who own cell phone and social media addiction. 
Table 3

Association between owning a cell phone and social media addiction $(\mathrm{N}=318)$

\begin{tabular}{|c|c|c|c|c|}
\hline \multirow[t]{2}{*}{ Adolescents with their cell phone } & \multicolumn{2}{|l|}{ SMAS-SF } & \multirow[t]{2}{*}{ Chi-Square value } & \multirow[t]{2}{*}{ p-value } \\
\hline & Addicted & Not addicted & & \\
\hline Yes & 67.8 & 56.4 & \multirow[t]{2}{*}{4.350} & \multirow[t]{2}{*}{$0.037^{a}$} \\
\hline No & 32.2 & 43.6 & & \\
\hline Source: Field survey, 2020 & & & & \\
\hline
\end{tabular}

Table 4 discloses the prevalence of depression among adolescents based on SMFQ scores. Out of 318 adolescents, 31.8 percent scored more than 8 and were found depressed; 68.2 percent scored below 7 and were not depressed.

Table 4

Short mood and feelings questionnaire (SMFQ) related findings ( $N=318)$

\begin{tabular}{|llll|}
\hline Responses & Not true & Sometimes & True \\
\hline I felt miserable or unhappy. & 37.7 & 59.7 & 2.5 \\
\hline I didn't enjoy anything at all. & 73.0 & 23.9 & 3.1 \\
\hline I felt so tired I just sat around and did nothing. & 40.9 & 47.8 & 11.3 \\
\hline I was very restless, disturbed, troubled. & 58.5 & 34.0 & 7.5 \\
\hline I felt I was no good any more. & 58.5 & 33.6 & 7.9 \\
\hline I cried a lot. & 73.3 & 18.9 & 7.9 \\
\hline I found it hard to think properly or concentrate. & 37.4 & 46.9 & 15.7 \\
\hline I hated myself & 79.9 & 16.7 & 3.5 \\
\hline I was a bad person. & 78.3 & 16.0 & 5.7 \\
\hline I felt lonely. & 56.6 & 34.3 & 9.1 \\
\hline I thought nobody loved me. & 66 & 27.0 & 6.9 \\
\hline I thought I could never be as good as other kids. & 53.5 & 37.1 & 9.4 \\
\hline I did everything wrong. & 72.3 & 23.3 & 4.4 \\
\hline Source: Field survey, 2020 & & & \\
\hline
\end{tabular}


Out of total 101(31.8\%) depressed adolescents, 64.4 percent of them had social media addiction. Association between social media addiction and depression has been measured by using the Chi-square test. Since the $p$-value was less than $0.05(p=0.000)$, Table 5 reveals that there is a significant relationship between social media addiction and depression.

Table 5

Association between social media addiction and depression ( $N=318)$

\begin{tabular}{|c|c|c|c|c|}
\hline \multirow[t]{2}{*}{ Social media addiction } & \multicolumn{2}{|c|}{ Level of depression } & \multirow[t]{2}{*}{ Chi-square value } & \multirow[t]{2}{*}{$\mathrm{p}$-value } \\
\hline & Depressed & Not depressed & & \\
\hline Yes & 64.4 & 37.3 & \multirow[t]{2}{*}{20.277} & \multirow[t]{2}{*}{$0.000^{b}$} \\
\hline No & 35.6 & 62.7 & & \\
\hline \multicolumn{5}{|c|}{ Source: Field survey, 2020} \\
\hline
\end{tabular}

\section{Discussion}

Social media is a digital tool that allows people to easily stay connected and produce content through applications for different mobile devices and operating systems [17]. Nowadays, people use social media more commonly than expected. The previous study has shown that excessive and pathological use of social media leads to personal, social, vocational, and educational problems for individuals. However, due to the conceptual confusion surrounding the classification of problematic internet use, there is no consensus among researchers regarding the identification of problematic social networking or internet addiction [18]. It has been noted that the increase in mental distress and deterioration of mental health conditions of adolescents has paralleled with the rapid rise in the use of cell phones and social media by adolescents. Evidence of a variety of cross-sectional, longitudinal, and empirical studies have shown the link between cell phone and social media use and the increase in mental distress and self-injurious behavior among youth. A cross-sectional study done among undergraduate students of University in the Northeastern United States reported negative effects increased by the excessive use of social media, which may have harmful effects on personal and social lives of the users [19], and another study also disclosed that the students of Southwestern University were found feeling depressed after spending an extensive amount of time on social media [20].

In Nepal, the internet penetration rate is just about 15 percent and very few students use the internet for educational purposes so it is very likely that students, guardians, and possibly teachers view the internet as a medium of entertainment and not an educational resource [21]. In this context, the current study aims to assess the psychological effects of social media among adolescent students (10-19 yrs) of Grade 9 and 10 in schools of Kathmandu city in Nepal. Using social networking sites is a particularly popular activity to connect with social media via mobile technologies. Current study finding shows that 61.6 percent of the adolescents had their phones and a large proportion (88.1\%) of the respondents had 
internet facilities in their houses. Besides, the average time spent on social media was 2.44 hours in a day and a large proportion (54.4\%) of the respondents spent 1 to 5 hours in social media. Previous studies have reported variations in time spent on social media. A cross-sectional study done among school adolescents in Hungary reported 3.3 hours average time spent on social media and 38.6 percent of the respondents spent more than 3 hours on social media [22]. Another study was done in China among 1840 years aged group disclosed that 23 percent of the participants spent three hours or more on social media [23].

In the past, studies were also done to assess problems and mobile phone use has proliferated those results and has suggested that some individuals may develop addiction-related problems as a consequence of their mobile phone use [24]. Social media addiction is also considered a kind of internet addiction [25]. People spending too much time on social media can cause the effects like virtual tolerance, virtual communication, and virtual problem and the behaviors that force the person into these actions can be explained as a social media addiction. In this context, the results of the current study also revealed that out of 318 adolescence respondents, 45.9 percent of them were addicted to social media. Based on SMAS-SF, the current study revealed virtual tolerance (15.7\%), virtual communication (33\%), virtual problem (28.5\%), and virtual information (22.8\%) respectively. In a study done in Hungary, social media addiction was assessed based on Bergen Social Media Addiction Scale (BSMAS). The BSMAS scale has categorized the level of social media addiction into three classes. The first class named 'norisk', second class 'low risk' and third-class 'at risk'. This BSMAS based result showed that 78.3 percent of social media users were in 'no risk', the second class of social media users represented 'low risk' of problematic use ( $17.2 \%$ and $15.5 \%$ respectively) and the third class represented the population of 'at-risk' problematic social media users were 4.5 percent, and 4.1 percent, respectively [22].

We observed that previous research findings also suggest younger generations may be more at risk in developing addictive symptoms as a consequence of their social media use-whilst perceptions of social media addiction appear to differ across generations [26]. Our current study concluded that 31.8 percent of the adolescents were depressed and it is surprising that 64.4 percent of them had social media addiction. Besides, the significant association is observed between adolescents with their cell phone and social media addiction ( $p=0.037)$; social media addiction and depression $(p=0.000)$. In this context, previous studies have also reported that mobile phone use is a condition, with dependent use being one possible consequence, like addictive behavior to social media [24, 27]. A study on a sample of over 23,000 Norwegians also supported this supposition by specifically indicating that social networking is often engaged in via phones, which may contribute to addiction to social media [28]. Another crosssectional study focused on higher secondary students in Chennai of India has also concluded that cell phone usage is so strongly integrated into young people's behavior that it was showing resulting in symptoms of behavioral addiction [29]. We also noted that the previous studies show differences in prevalence rates of negative psychological effects of social media use was mainly due to various methodological issues such as sampling techniques and sample size, targeting mainly college students and small sample sizes [30-33]. For instance, the prevalence of problematic social media users among Nigerian University undergraduates was 1.6 percent [34] and in Jordan, 38.5 percent of ordinary users 
were found addicted to Facebook [35]. Also, a cross-sectional study done among adult group reported a significant positive correlation between depression symptoms and social media use [28], positive correlation between social media addiction and depression has also been noted among University students in Afghanistan [36]. Furthermore, a study was done in the Department of Psychology, University of Sargodha, Punjab, Pakistan declared a negative relationship between self-esteem and high levels of social media use [37]. We noted that the results of previous studies were corresponding to the prevalence rates of the general addictive internet use among different age groups rather than in adolescents that range between 1 percent [38] to 18.7 percent [39]. Previous review study has also pointed out that many studies do not clarify the differences between internet addiction and gambling and making comparisons across study limitation, study design and sampling techniques [40]. While our current study finding is based on probability sampling techniques and is conducted among adolescent students (10-19 yrs) of City area that are at higher risk of negative psychological effects of social media use. Thus, the results of this study hold important implications for adolescents of schools and colleges who are addicted and depressed and might also be addicted to social media.

We conducted this non-interventional cross-sectional school-based study in schools of Kathmandu City in Nepal and findings are based on SMAS-SF and SMFQ. Percent comparisons are done for descriptive analysis and Chi-square test has been used to measure the association between the variables. Therefore, causality cannot be established regarding the risk factors through this study design. Future research might apply to different study design (i.e., interventional, longitudinal designs) to identify the contributing factors of the psychological effects among social media using adolescents and future interventions might also target the reduction of social media use among those adolescents who are at risk of addiction and depression. Besides, it should be noted that when completing the Social Media Addiction Scale and Short Mood \& Feelings Questionnaire, the research participants may have had a different conception of social media use than intended by the developers of the Social Media Addiction Scale and Short Mood \& Feelings Questionnaire.

\section{Conclusions}

Prevalence of negative psychological effects due to inappropriate use of social media among schoolgoing adolescents is alarming in Nepal. Adolescents with access to personal cell phones, availability of internet facility in-home and dedicate more hours to social media are the main contributing factors to the increase in the prevalence of social media addiction among adolescents. Social media addiction is the contributing risk factor for depression, suggesting the urgent need to develop policies and programs to mitigate the negative psychological effects of cell phones and social media addiction. Besides, policymakers, parents, schools, and health workers must make adolescents aware of the link between the use of cell phone and its negative psychological effects.

\section{Abbreviations}

BSMAS 
Bergen Social Media Addiction Scale; NHRC:Nepal Health Research Council; PPS:Probability Proportional to Size; SMAS-SF:Social Media Addiction Scale Student Form; SMFQ:Short Mood and Feelings Questionnaire; SPSS:Statistical Package for Social Sciences.

\section{Declarations}

\section{Ethical approval and consent to participate}

This study has been approved by Ethical Review Board of Nepal Health Research Council of Nepal (ERB protocol number 451/2019) and study has been conducted in accordance with the Declaration of Helsinki. This is a cross sectional study and written informed consent was obtained from the research participants.

\section{Consent for publication}

Not applicable

\section{Availability of data and materials}

The datasets generated and/or analyzed during the current study are available from the corresponding author on reasonable request.

\section{Competing interests}

The authors have no competing interests to disclose.

\section{Funding}

This research did not receive any specific grant from funding agencies in the public, commercial, or notfor-profit sectors.

Author's contribution statement: Ashok Kumar Paudel - Conceptualization, Methodology, Formal analysis, Writing-preparation of original draft, Writing-reviewing \& editing. Muni Raj Chhetri - Project administration, Validation, Investigation, Resources Data curation, Writing-reviewing \& editing. Prinisha Baidya Supervision, Software, Data curation, Visualization, Validation.

\section{Acknowledgements}

We acknowledge the management of the schools for their support; teacher staffs for facilitating the study and appreciate respondents for their valuable time and kind cooperation.

\section{Author's details}

${ }^{1}$ Department of Public Health, National Open College, Pokhara University, Lalitpur, Nepal. Email: ashokkpaudel@gmail.com 
${ }^{2}$ Karnali Academy of Health Sciences, Jumla, Nepal. Email: munichhetri@gmail.com

${ }^{3}$ Department of Public Health, National Open College, Pokhara University, Lalitpur, Nepal. Email: prinishabaidya123@gmail.com

\section{References}

1. Matthew H. What is social media? The balance small business; 2019. Available at: https://www.thebalancesmb.com/what-is-social-media-2890301. Assessed January 22, 2020.

2. Daniel N. What is social media? Lifewire; 2019. Available at: https://www.lifewire.com/what-is-socialmedia-explaining-the-big-trend-3486616. Accessed January 13, 2020.

3. Lenhart A, Purcell K, Smith A, Zickuhr K. Social media and mobile internet use among teens and young adults. Washington, DC: Pew Internet \& American Life Project; 2010.

4. Lenhart A, Duggan M, Perrin A, Stepler R, Rainie H, Parker K. Teens, social media and technology overview. Smart phones facilitate shifts in communication landscape for teens. Washington, DC: Pew Internet \& American Life Project; 2015.

5. Ahn J. The effect of social network sites on adolescents' social and academic development: Current theories and controversies. Journal of the American Society for Information Science and Technology. 2011;62:1435-45. DOI: https://doi.org/10.1002/asi.21540.

6. Kuss DJ, Griffiths MD. Online social networking and addiction: A review of the psychological literature. International Journal of Environmental Research and Public Health. 2011;8:3528-52. DOI: https://doi.org/10.3390/ijerph8093528.

7. Boyd DM, Ellison NB. Social network sites: Definition, history, and scholarship. Journal of Computer Mediated Communication. 2007;13:210-30. DOI: https://doi.org/10.1111/j.10836101.2007.00393.x.

8. Kuss DJ, Griffiths MD. Excessive online social networking: Can adolescents become addicted to Facebook? Education and Health. 2011;29:68-71. Available at: http://sheu.org.uk/sheux/EH/eh294mg.pdf. Accessed June 7, 2020.

9. Ryan T, Chester A, Reece J, Xenos S. The uses and abuses of Facebook: A review of Facebook addiction. Journal of Behavioral Addictions. 2014;3:133-48. DOI: https://psycnet.apa.org/doi/10.1556/JBA.3.2014.016.

10. Griffiths MD. Adolescent gambling and gambling type games on social networking sites: Issues, concerns, and recommendations. Aloma. 2015;33:31-37. Available at: http://irep.ntu.ac.uk/id/eprint/26766/1/4094_Griffiths.pdf. Accessed November 14, 2020.

11. Ochs J. The negative effects of social media for teens. Smart Social; 2019. Available at: https://smartsocial.com/negative-effects-of-social-media/. Accessed June 7, 2020.

12. Mihalyi C. Adolescence. Encyclopædia Britannica, inc.; 2019. Available at: https://www.britannica.com/science/adolescence. Accessed August 19, 2020. 
13. Şahin C. Social media addiction scale- student form: The reliability and validity study. Turkish Online J Educ Technol. 2018;17:169-82. Available at: http://www.tojet.net/articles/v17i1/17117.pdf. Accessed October 12, 2020.

14. Rhew IC, Simpson K, Tracy M, et al. Criterion validity of the short mood and feelings questionnaire and one and two-item depression screens in young adolescents. Child Adolesc Psychiatry Ment Health. 2010;4. DOI: https://doi.org/10.1186/1753-2000-4-8.

15. Thabrew H, Stasiak K, Bavin LM, Frampton C, Merry S. Validation of the mood and feelings questionnaire (MFQ) and short mood and feelings questionnaire (SMFQ) in New Zealand help seeking adolescents. Int J Methods Psychiatr Res. 2018;27:e1610. DOI: https://doi.org/10.1002/mpr.1610.

16. Kuo ES, Stoep AV, Stewart DG. Using the short mood and feelings questionnaire to detect depression in detained adolescents. Assessment. 2005;12:374-383. DOI: https://doi.org/10.1177/1073191105279984.

17. Hudson M. What is social media?.The balance small bussiness; June 23, 2020. Avialable at: https://www.thebalancesmb.com/what-is-social-media-2890301. Accessed December 9, 2020.

18. Wegmann E, Stodt B, Brand M. Addictive use of social networking sites can be explained by the interaction of internet use expectancies, internet literacy, and psychopathological symptoms. Journal of Behavioral Addictions. 2015;4(3):155-162. Available at:

https://www.ncbi.nlm.nih.gov/pmc/articles/PMC4627676/pdf/jba-04-155.pdf. Accessed November 2, 2020 .

19. Hormes JM. Under the influence of Facebook? Excess use of social networking sites and drinking motives, consequences, and attitudes in college students. J Behav Addict. 2016;5(1):122-129. DOI: https://dx.doi.org/10.1556\%2F2006.5.2016.007

20. Steers MN, Wickham RE, Acitelli LK. Seeing everyone else's highlight reels: How Facebook usage is linked to depressive symptoms. Journal of Social and Clinical Psychology. 2014;33(8):701-731. Available at: https://guilfordjournals.com/doi/pdf/10.1521/jscp.2014.33.8.701. Accessed November 6, 2020.

21. Acharya S. Internet usage of teenagers in Nepal for educational purposes. An analysis of internet usage behaviour of 15-17-year old students at selected schools in Kathmandu. 2016. DOI: https://doi.org/10.13140/RG.2.2.18670.87360.

22. Bányai F, Zsila Á, Király O, et al. Problematic social media use: Results from a large-scale nationally representative adolescent sample. PLoS One. 2017;12:10-14. DOI: https://doi.org/10.1371/journal.pone.0169839.

23. Wu AMS, Cheung VI, Ku L, Hung EPW. Psychological risk factors of addiction to social networking sites among Chinese smartphone users. J Behav Addict. 2013;2:160-6. DOI: https://dx.doi.org/10.1556\%2FJBA.2.2013.006.

24. Fernandez OL, Kuss DJ, Griffiths MD, Billieux J. The conceptualization and assessment of problematic mobile phone use. In Z. Yan (Ed.), Encyclopedia of Mobile Phone Behavior. 2015; Vol. 1, 
2 \& 3, pp. 591-606. Hershey, PA. DOI: https://doi.org/10.4018/978-1-4666-8239-9.ch050.

25. Kuss DJ, Griffiths MD. Internet and gaming addiction: A systematic literature review of Neuroimaging studies. Brain Sci. 2012:2:347-374. DOI: https://dx.doi.org/10.3390\%2Fbrainsci2030347.

26. Griffiths MD, Kuss D. Adolescent social media addiction (revisited). Education and Health. 2017;35(3):49-52. URI: http://irep.ntu.ac.uk/id/eprint/31776

27. Billieux J, Maurage P, Lopez-Fernandez O, Kuss DJ, Griffiths MD. Can disordered mobile phone use be considered a behavioral addiction? An update on current evidence and a comprehensive model for future research. Current Addiction Reports. 2015;2:156-162. DOI: https://doi.org/10.1007/s40429015-0054-y.

28. Andreassen CS, Billieux J, Griffiths MD, et al. The relationship between addictive use of social media and video games and symptoms of psychiatric disorders: A large-scale cross-sectional study. Psychology of Addictive Behaviors. 2016;30:252-262. DOI: https://doi.org/10.1037/adb0000160.

29. Kritika M, Vasanta $S$. The mobile phone usage among teens and young adults impact of invading technology. International Journal of Innovative Research in Science, Engineering and Technology. 2013;2(12):7259-7265. Available at: http://www.ijirset.com/upload/2013/december/29_TheMobile.pdf. Accessed March 24, 2020.

30. Zhou SX. Gratifications, loneliness, leisure boredom and self-esteem as predictors of SNS-game addiction and usage pattern among Chinese college students [dissertation]. Hong Kong: Chinese University of Hong Kong; 2010. Available at: http://pg.com.cuhk.edu.hk/pgp_nm/projects/2010/Selina\%20Zhou_Final.pdf. Accessed March 27, 2020.

31. Wilson K, Fornasier S, White KM. Psychological predictors of young adults' use of social networking sites. Cyberpsychology, Behavior, and Social Networking. 2010;13:173-7. Available at: https://eprints.qut.edu.au/31794/3/31794.pdf. Accessed November 27, 2020.

32. Wan C. Gratifications and loneliness as predictors of campus-SNS websites addiction and usage pattern among Chinese college students [dissertation]. Hong Kong: Chinese University of Hong Kong, China; 2009. Available at: http://pg.com.cuhk.edu.hk/pgp_nm/projects/2009/Wan\%20Sisi\%20Candy.pdf. Accessed April 28, 2020.

33. Wolniczak I, Caceres-DelAguila JA, Palma-Ardiles G, et al. Association between Facebook dependence and poor sleep quality: A study in a sample of undergraduate students in Peru. PLoS ONE. 2013;8:e59087. DOI: https://doi.org/10.1371/journal.pone.0059087.

34. Alabi OF. A survey of Facebook addiction level among selected Nigerian University undergraduates. New Media and Mass Communication. 2013;10:70-80. DOI: https://doi.org/10.7176/NMMC.VOL1070-80.

35. Alzougool B. The impact of motives for Facebook use on Facebook addiction among ordinary users in Jordan. International Journal of Social Psychiatry. 2018;64(6):528-535. DOI: https://doi.org/10.1177/0020764018784616. 
36. Haand R, Suwang Z. The relationship between social media addiction and depression: A quantitative study among university students in Khost, Afghanistan. International Journal of Adolescence and Youth. 2020;25:780-786. DOI: https://doi.org/10.1080/02673843.2020.1741407.

37. Malik S, Khan M. Impact of facebook addiction on narcissistic behavior and self-esteem among students. Journal of Pakistan Medical Association. 2015;65:260-3. Available at: https://www.jpma.org.pk/article-details/7283. Accessed June 19, 2020.

38. Rumpf H-J, Vermulst AA, Bischof A, Kastirke N, Guertler D, Bischof G, et al. Occurrence of internet addiction in a general population sample: A latent class analysis. Eur Addict Res. 2013;20(4):15966. DOI: https://doi.org/10.1159/000354321.

39. Lin I-H, Ko C-H, Chang Y-P, Liu T-L, Wang P-W, Lin H-C, et al. The association between suicidality and Internet addiction and activities in Taiwanese adolescents. Compr Psychiatry. 2014;55(3):504-10. DOI: https://doi.org/10.1016/j.comppsych.2013.11.012.

40. Pontes HM, Kuss D, Griffiths M. Clinical psychology of internet addiction: A review of its conceptualization, prevalence, neuronal processes, and implications for treatment. Neuroscience and Neuroeconomics. 2015;4:11-23. DOI: https://doi.org/10.2147/NAN.S60982. 